\title{
SEASONAL MATURATION OF Glypthelmins vitellinophilum (TREMATODA: DIGENEA) IN Lysapsus limellus (ANURA: PSEUDIDAE) FROM AN ARGENTINIAN SUBTROPICAL PERMANENT POND
}

\author{
HAMANN, M. I. \\ Centro de Ecología Aplicada del Litoral - CECOAL, \\ Consejo Nacional de Investigaciones Científicas y Técnicas - CONICET, \\ Casilla de Correo, 291, 3400, Corrientes, Argentina \\ Correpondence to: Monika Inés Hamann, Centro de Ecología Aplicada del Litoral - CECOAL, \\ Consejo Nacional de Investigaciones Científicas y Técnicas - CONICET, \\ Casilla de Correo, 291, 3400, Corrientes, Argentina, e-mail: monika_hamann@yahoo.com \\ Received June 25, 2003 - Accepted January 20, 2004 - Distributed February 28, 2006
}

(With 3 figures)

\begin{abstract}
From December 1995 to November 2000, the seasonal maturation of Glypthelmins vitellinophilum Dobbin, 1958, in its definitive host, the frog Lysapsus limellus Cope, 1862, was studied in a subtropical permanent pond in northeastern Argentina. The objectives of this study were: 1) to determine the infrapopulation dynamics of the parasite, analyzing the seasonal maturation cycle throughout the years; and 2) to examine the relationship between the intensity of trematode infection in different developmental stages (recruitment, growth and maturation) and the host's body length. Of a total of 1,400 frogs examined over 60 months (5 years), 38\% were found to be infected with G. vitellinophilum, and the intensity of infection was 1-15 trematodes per frog. Specimens of G. vitellinophilum were present in L. limellus throughout the years, but did not show a pronounced seasonal maturation cycle. Possible reasons for these findings are discussed with reference to climatic fluctuations and biotic factors. The infective period of the parasite (stage I) occurred in summer, autumn and spring, coinciding with the time each frog cohort appeared. These infections were found principally in small body sizes (classes 1 and 2) of L. limellus. Juvenile and nongravid specimens of worms (stage II and III) were found in frogs of different body sizes throughout the period of investigation. Gravid specimens of the parasite (stage IV) were generally recorded in autumn, winter and spring, mainly in the bodies of larger frogs. The body length of Trematodes in stages I and IV was significantly and positively correlated with that of the frogs.
\end{abstract}

Keywords: Digenea, Glypthelmins vitellinophilum, ecology, parasite maturation, subtropical region, Argentina.

\section{RESUMO}

\section{Maturação sazonal de Glypthelmins vitellinophilum (Trematoda: Digenea) em Lysapsus limellus (Anura: Pseudidae) em uma lagoa permanente subtropical da Argentina}

De dezembro de 1995 a novembro de 2000, a maturação sazonal de Glypthelmins vitellinophilum Dobbin, 1958, em seu hospedeiro definitivo, a rã Lysapsus limellus Cope, 1862, foi estudada em uma lagoa permanente subtropical no nordeste da Argentina. Os objetivos deste estudo foram: 1) determinar a dinâmica de infrapopulação do parasita, analisando o ciclo de maturação sazonal ao longo dos anos; e 2) examinar a relação entre intensidade de infecção do trematódeo em diferentes estádios do desenvolvimento (recrutamento, crescimento e maturação) e o comprimento de corpo da rã. De 1.400 espécimens de rãs em 60 meses (5 anos), foram achados 38\% infetados com G. vitellinophilum, e a intensidade de infecção era 1-15 trematódeos por rã. Espécimes de G. vitellinophilum estavam presentes em L. limellus ao longo dos 
anos, mas não mostraram um ciclo sazonal pronunciado de maturação. São discutidas possíveis razões para estes resultados com referência a flutuações climáticas e fatores bióticos. O período infectante do parasita (estádio I) aconteceu no verão, outono e primavera, coincidentemente com o tempo de aparecimento de cada corte das rãs. Estas infecções eram principalmente registradas em tamanhos de corpo pequenos (classes 1 e 2) de L. limellus. Espécimes de parasitas juvenis e não grávidas (estádios II e III) eram encontradas em diferentes tamanhos de rãs ao longo do período de investigação. Espécimes de parasitas grávidas (estádio IV) eram geralmente registradas no outono, inverno e primavera, principalmente nos tamanhos de corpo maiores de rãs. O comprimento de corpo do trematódeo dos estádios I e IV eram significativa e positivamente correlatos com o comprimento de corpo da rã.

Palavras-chaves: Digenea, Glypthelmins vitellinophilum, ecologia, maturação de parasita, região subtropical, Argentina.

\section{INTRODUCTION}

The dynamics of an infrapopulation of Glypthelmins vitellinophilum Dobbin, 1958 was analyzed in a subtropical semi-permanent habitat by Hamann and Kehr (1999), while the influence of biotic and abiotic factors in relation to parasite infracommunity structures in different subtropical habitats has been studied by Kehr et al. (2000). However, data on the seasonal patterns of maturation of G. vitellinophilum are nonexistent, while information about the developmental relationships between host and parasite is only partial. The body length of the L. limellus host is one of the factors possibly associated with the development of $G$. vitellinophilum in a semipermanent pond (Hamann \& Kehr, 1999). Therefore, this paper reports on the first observation of the seasonal maturation cycle of $G$. vitellinophilum under natural conditions in a subtropical region of Argentina.

The definitive host Lysapsus limellus is a member of the frog family Pseudidae, which occurs exclusively in South America (Duellman \& Trueb, 1986). In Argentina, L. limellus is restricted to some areas adjacent to the Paraguay and Paraná Rivers. This frog displays a strong preference for aquatic habitats and occurs in permanent and semipermanent ponds.

Based on certain assumptions, the approach employed in this study predicts a direct relationship between parasite maturation and the reproductive cycle of the host and seasonal and abiotic factors. Therefore, this study purported: 1) to determine the population dynamics of the parasite, analyzing the seasonal maturation cycle throughout the years; and 2) to analyze the relationship between the intensity of parasite infection in different developmental stages (recruitment, growth and maturation) and the host's body length.

\section{MATERIAL AND METHODS}

\section{Study site}

The habitat studied here is a permanent pond located $30 \mathrm{Km}$ from the city of Corrientes, province of Corrientes, Argentina (27 $25^{\prime} \mathrm{S} ; 58^{\circ}$ $\left.40^{\prime} \mathrm{W}\right)$. The predominant aquatic vegetation is Salvinia sp., Ludwigia sp. and Nymphoides sp. This oval pond has a surface area of approximately two hectares, with well-defined banks and a maximum depth of $2 \mathrm{~m}$.

\section{Analytical procedure and statistical analysis}

Specimens were collected monthly from December 1995 to November 2000. Sampling time was half an hour. The specimens were always collected by two people between 09:00 and 12:00 h. Every possible microhabitat was included in each sampling, and each specimen was collected with a fine meshed (width: $65 \mathrm{~cm}$, height: $45 \mathrm{~cm}$, depth: $45 \mathrm{~cm}$ ) rectangular-framed dip net. The frogs were taken to the laboratory, placed in an ether solution and their snout-vent length (SVL) measured. The SVLs were used to describe the host size and were divided into four arbitrary classes: 1 (under $12.1 \mathrm{~mm}$ ), 2 (12.1 to under $15 \mathrm{~mm}$ ), 3 (15 to under $17 \mathrm{~mm}$ ) and 4 (17 $\mathrm{mm}$ or longer).

In the necropsy, the hosts were sexed and their intestines removed and examined. Glypthelmins vitellinophilum were withdrawn from the small intestine of infected frogs, counted and fixed 
with warm Raillet-Henry solution, then stained with alcoholic hydrochloric carmine, cleared in creosote and mounted in Canada balsam. These trematodes were measured for total length (in micrometers). The measurements were taken with an ocular micrometer, and the withdrawals were completed using a drawing tube. Specimens were deposited in the Helminthological Collection of the Centro de Ecología Aplicada del Litoral (Center of Applied Ecology of the Littoral) under the codes CECOAL9512136 (stage I), CECOAL9609535 (stage II), CECOAL9608529 (stage III) and CECOAL9702663 (stage IV). Prevalence and mean intensity of infection were calculated as described by Bush et al. (1997), and the two variables were used to determine the distribution of trematodes in relation to the host's body length.

Two null hypotheses were established: 1) the intensity of infection by G. vitellinophilum (stages I, II, III, and IV) was similar throughout every month of each year of this study; and 2) there was no relationship between the body length of the infected host and the intensity of infection in the different developmental stages of the parasite. The non-parametric Friedman Test $\left(\mathrm{x}_{\mathrm{r}}^{2}\right)$, which allows for a two-factor ANOVA, was applied to test the first hypothesis. A Chi-square $\left(\mathrm{x}^{2}\right)$ statistical comparisons test to ascertain the independence of the developmental stage versus the host's body length was applied to evaluate the second hypothesis. In addition, a simple regression analysis was made to determine the relation between the parasite's body length per stage and the host's SVL. This analysis involved frogs hosting only one parasite. The data of the parasite's body length $(\mu \mathrm{m})$ and the host's body length $(\mathrm{mm})$ were logarithmically normalized. Statistical analyses were carried out according to Zar (1996). The statistical tests were carried out using SYSTAT 7.0 software for Windows. Codes were used to indicate the seasons, as follows: $1=$ summer (21 Dec-20 Mar), 2 = autumn (21 Mar20 Jun), 3 = winter (21 Jun-20 Sep) and $4=$ spring (21 Sep-20 Dec).

\section{RESULTS}

Of the 1,400 frogs examined over 60 months (5 years), $38 \%$ were infected with G. vitellinophilum in the small intestine, and the intensity of infection was $1-15$ trematodes per frog (mean intensity $=2.1$; abundance $=0.9$; and variance $/$ mean ratio $=2.6$ ) .

In order to clarify the development of G. vitellinophilum, the parasites were assigned to four stages based on the relative degree of development of their reproductive systems and their body length. Stage I: rudimental gonad, vitellaria absent and body length range $150-550 \mu \mathrm{m}$ (mean $356 \mu \mathrm{m}$ ) (Figs. 1a, 1b); Stage II: well developed gonads, functional vitellaria and body length range 250-1060 $\mu \mathrm{m}$ (mean $593 \mu \mathrm{m}$ ) (Fig. 1c); Stage III: fully developed genitalia, functional vitellaria, eggs in uterus (less than 100 eggs) and body length range 400-1320 $\mu \mathrm{m}$ (mean $886 \mu \mathrm{m}$ ) (Fig. 1d); and Stage IV: gravid worm's eggs filling uterus and body length range 600-2505 $\mu \mathrm{m}$ (mean $1272 \mu \mathrm{m}$ ) (Fig. 1e).

\section{Parasite maturation in relation to seasonal effect}

Seasonal changes in maturation of G. vitellinophilum and its occurrence throughout the year were studied in L. limellus for five years. The findings differed according to the different stages of trematode development (Fig. 2). Gravid worms (stage IV) were present in every season and their intensity of infection revealed significant differences among years $\left(\mathrm{x}_{\mathrm{r}}^{2}=19.22\right.$, $\mathrm{df}=4$, $\mathrm{P}<0.001$ ). Nongravid specimens (stage III) were consistently low throughout the years and their intensity of infection showed significant differences among years $\left(\mathrm{x}_{\mathrm{r}}^{2}=13.78\right.$, $\left.\mathrm{df}=4, \mathrm{P}<0.01\right)$. Likewise, there were significant differences in the intensity of infection of juvenile parasites (stage II) throughout the years $\left(\mathrm{x}^{2}=18.08, \mathrm{df}=4\right.$, $\mathrm{P}<0.001)$. However, no differences were found in the intensity of newly acquired infections (stage I) in the five years of study $\left(x_{r}^{2}=7.68, d f=4\right.$, $\mathrm{P}>0.5$ ).

In the first year (Dec 1995 to Nov 1996), infection by gravid worms (stage IV) was lower in summer and highest in autumn and winter. High recruitment of the parasite (stage I) occurred in spring and summer, while the relative number of juvenile worms (stage II) was also high in those seasons (Fig. 2a).

In the second (Dec 1996 to Nov 1997) and third years (Dec 1997 to Nov 1998), the developmental stages were not very representative, because they were limited by abiotic factors (e.g., low rainfall in the second year and very 

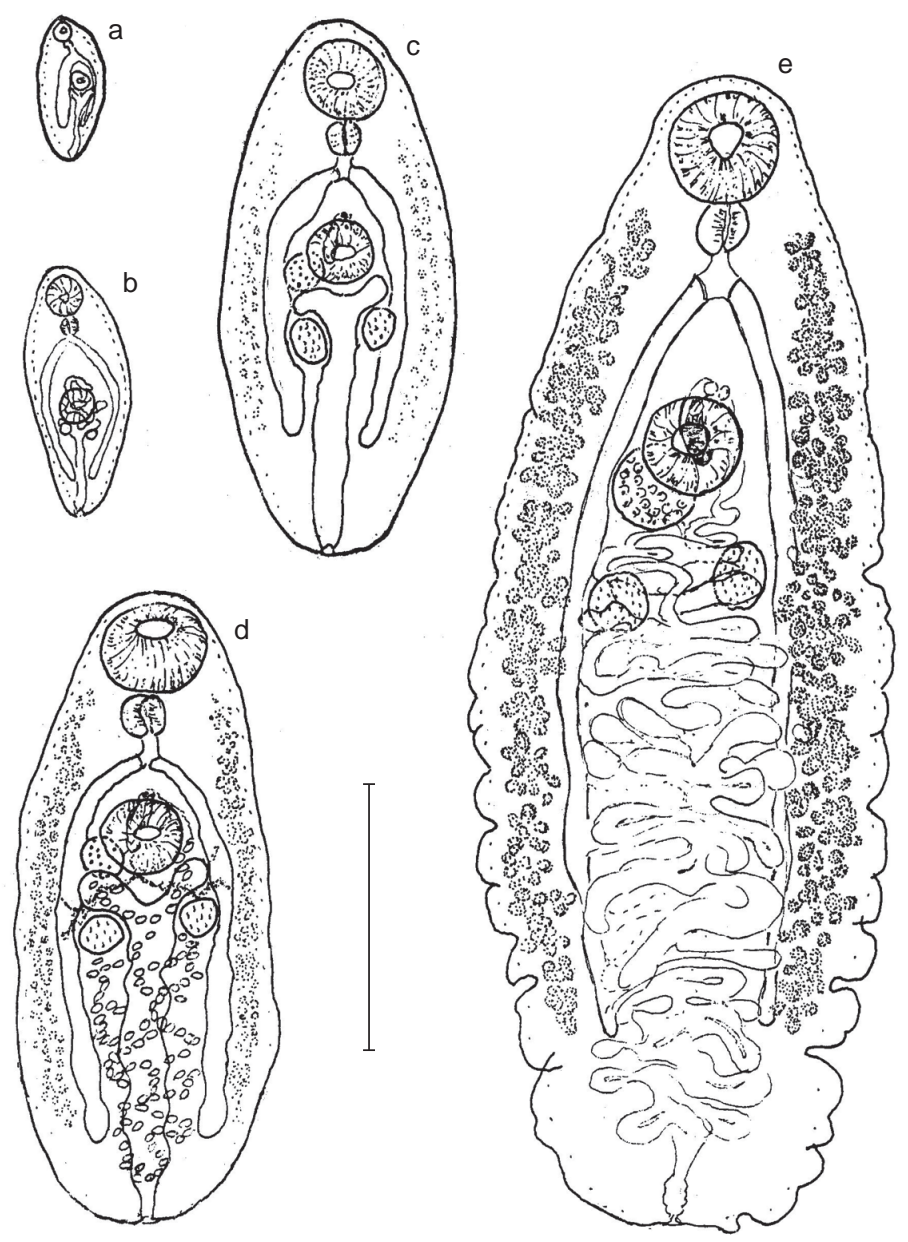

Fig. 1 - Specimens of Glypthelmins vitellinophilum Dobbin, 1958, bar = $0.5 \mathrm{~mm}$. a-b) Stage I (gonad rudiment), ventral view; c) Stage II (juvenile), ventral view; d) Stage III (nongravid), ventral view; and e) Stage IV (gravid), ventral view.

high rainfall in the third year) (Fig. 3). During the second year, infections by gravid worms (stage IV) and recruitment of the parasite (stage I) peaked in summer. Infections by juvenile (stage II) and maturing worms (stage III) were most frequent in autumn (Fig. 2b). In the third year, infections by the different trematode stages (I, II, II, and IV) were lower than in the preceding year (Fig. 2c).

In the fourth year (Dec 1998 to Nov 1999), the level of infection of new parasites (stage I) was high in summer and autumn. Infection by gravid worms (stage IV) was very high in winter, decreasing gradually in spring (Fig. 2d).

In the fifth year (Dec 1999 - Nov 2000), the stages of maturation varied in relation to the preceding years. Infection caused by new parasites (stage I) was low in summer and infection by gravid worms (stage IV) was abundant in spring (Fig. 2e).

\section{Parasite maturation in relation to host body size}

Table 1 shows the seasonal dynamics of prevalence, intensity of infection and number of parasites present in the four developmental stages in terms of years, season and frog size.

The results of the five years of investigation showed significant differences between the number of $G$. vitellinophilum parasites in the different stages and frog size (e.g., stage I vs. frog size: 


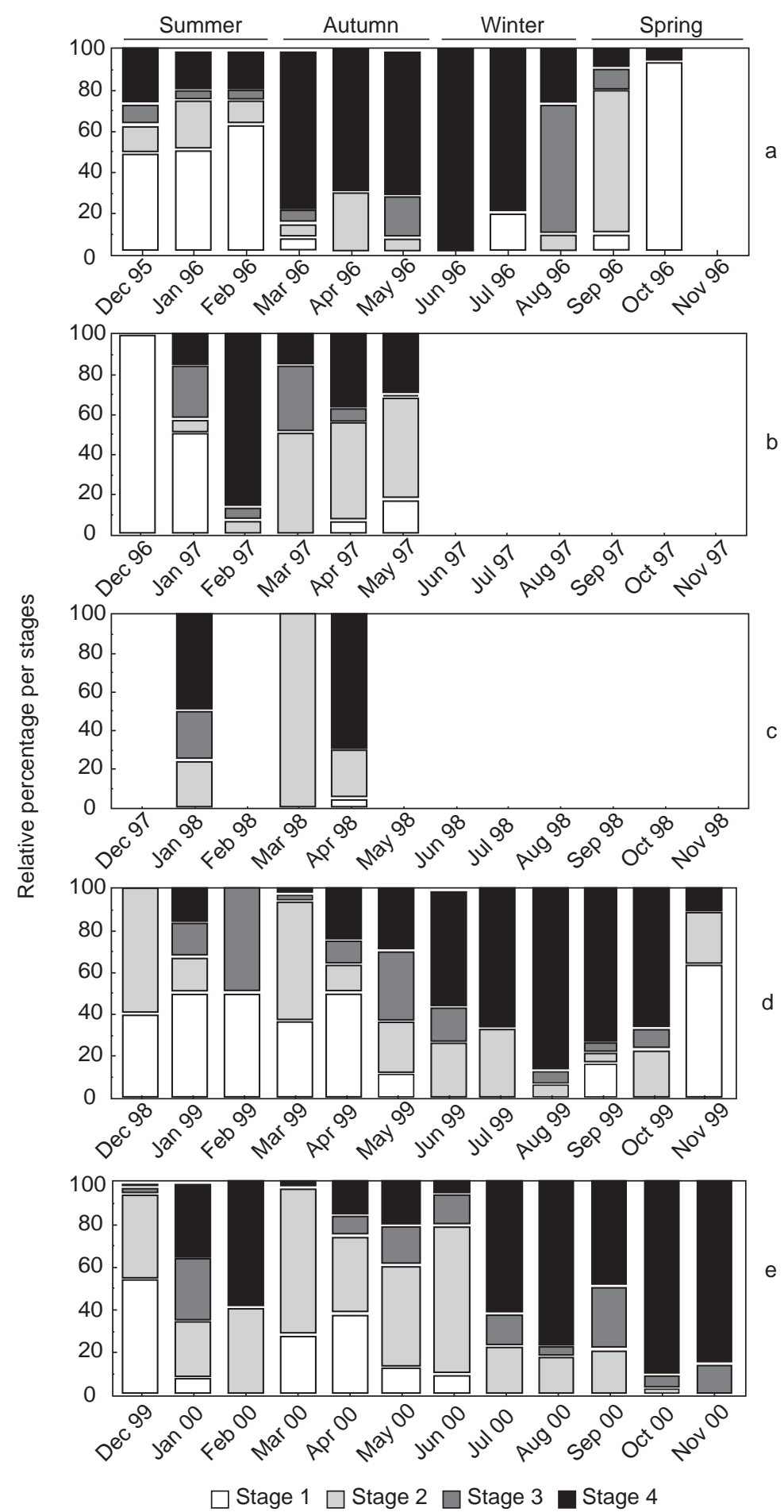

Fig. 2 - Distribution of maturation stages (I, II, III and IV) of Glypthelmins vitellinophilum Dobbin, 1958 in Lysapsus limellus Cope, 1862 during different years: a) 1995/1996; b) 1996/1997; c) 1997/1998; d) 1998/1999; and e) 1999/2000 (percentage of total worm population per month). 

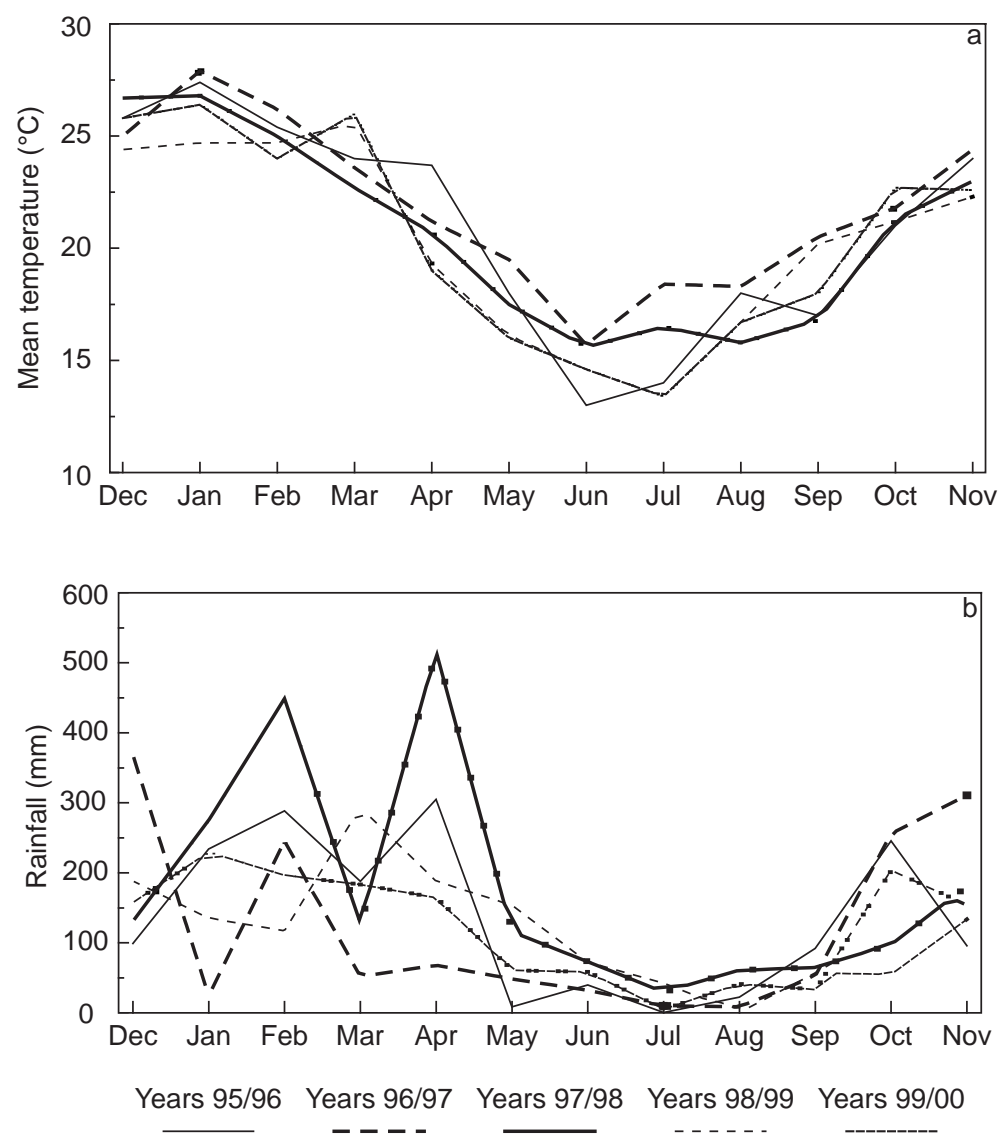

Fig. 3 - Environmental variables of the area surrounding the pond recorded monthly through the years. a) Temperature represents the monthly mean temperature; and b) rainfall represents monthly total $(\mathrm{mm})$ precipitation.

$\mathrm{x}^{2}=14.01, \mathrm{df}=3, \mathrm{P}<0.01 ;$ stage II vs. frog size: $\mathrm{x}^{2}=35.86, \mathrm{df}=3, \mathrm{P}<0.001$; stage III $v s$. frog size: $\mathrm{x}^{2}=34.34, \mathrm{df}=3, \mathrm{P}<0.001$ and stage IV vs. frog size: $\left.\mathrm{x}^{2}=226.81, \mathrm{df}=3, \mathrm{P}<0.001\right)$.

In addition, the body length of trematodes in stage I was significantly and positively correlated with the body length of frogs $(\log \mathrm{y}=1.47+$ 0.98. $\log \mathrm{x} ; \mathrm{n}=24 ; \mathrm{r}=0.45 ; \mathrm{F}=5.46 ; \mathrm{P}<0.05)$. Moreover, the body length of trematodes in stage IV was also significantly and positively correlated with the body length of frogs $(\log y=2.34+$ 0.63. $\log \mathrm{x} ; \mathrm{n}=77 ; \mathrm{r}=0.31 ; \mathrm{F}=8.21 ; \mathrm{P}<0.01)$. However, the body length of parasites in stage II was not significantly correlated with the body length of frogs $(\log y=2.88-0.08 . \log x$; $\mathrm{n}=55 ; \mathrm{r}=0.04 ; \mathrm{F}=0.10 ; \mathrm{P}>0.05)$. The number of parasites in stage III was low $(\mathrm{n}=11)$; hence, they were not considered in this analysis.

\section{DISCUSSION}

The digenean $G$. vitellinophilum has a two-host life cycle involving a snail as intermediate host and L. limellus as definitive host. Frog infection occurs via penetration by infective cercariae or by ingestion of infective metacercariae encysted in a tadpole or a young frog (Yamaguti, 1973; Grabda-Kazubska, 1976; Smyth \& Smyth, 1980). Interspecific relationships and effects on the ecological niches between G. vitellinophilum and other helminth species in the same host have been observed by Kehr et al. (2000).

During the five years of this investigation, G. vitellinophilum was consistently present in L. limellus. Other authors have observed the same frequency of occurrence of $G$. vitellinophilum in L. limellus (Hamann \& Kehr, 1999; Kehr 
TABLE 1

Stage of maturity, prevalence (\% infection) and mean (minimum - maximum) intensity of infection of Glypthelmins vitellinophilum in the host frog Lysapsus limellus by host size class, season and sampling year. No frogs were recorded in winter and spring of 1997 and 1998.

\begin{tabular}{|c|c|c|c|c|c|c|c|c|c|}
\hline & \multirow{2}{*}{$\begin{array}{c}\begin{array}{c}\text { Frog size } \\
\text { class }\end{array} \\
\end{array}$} & \multirow{2}{*}{$\begin{array}{l}\text { \# of frogs } \\
\text { analyzed }\end{array}$} & \multirow{2}{*}{$\begin{array}{c}\text { \# of frogs } \\
\text { infected }\end{array}$} & \multirow{2}{*}{$\begin{array}{c}\text { Prevalence } \\
(\%)\end{array}$} & \multirow[t]{2}{*}{ Mean intensity/min.-max. } & \multicolumn{4}{|c|}{ \# of worms in stages } \\
\hline & & & & & & I & II & III & IV \\
\hline \multirow{4}{*}{$\begin{array}{l}\text { Summer } \\
1995-1996\end{array}$} & 1 & 103 & 13 & 12.6 & $1.8 / 1-4$ & 15 & 4 & 2 & 2 \\
\hline & 2 & 57 & 18 & 31.6 & $2.0 / 1-7$ & 22 & 7 & 2 & 4 \\
\hline & 3 & 32 & 13 & 40.6 & $1.8 / 1-8$ & 13 & 3 & - & 3 \\
\hline & 4 & 21 & 11 & 52.4 & $1.9 / 1-4$ & - & 2 & 4 & 13 \\
\hline \multirow[t]{4}{*}{ Autumn 1996} & 1 & 10 & - & - & - & - & - & - & - \\
\hline & 2 & 23 & 4 & 17.4 & $1.2 / 1-2$ & 0 & 1 & 1 & 2 \\
\hline & 3 & 43 & 14 & 32.6 & $1.6 / 1-3$ & 2 & 4 & 2 & 13 \\
\hline & 4 & 54 & 27 & 50.0 & $1.6 / 1-4$ & - & 1 & 2 & 23 \\
\hline \multirow{4}{*}{$\begin{array}{l}\text { Winter } \\
1996\end{array}$} & 1 & 2 & 1 & 50.0 & $/ 1$ & 1 & - & - & - \\
\hline & 2 & 11 & 1 & 9.1 & $/ 1$ & - & - & - & 1 \\
\hline & 3 & 23 & 6 & 26.1 & $2.3 / 1-5$ & - & 1 & 5 & 6 \\
\hline & 4 & 23 & 5 & 21.7 & $1.4 / 1-2$ & - & - & 2 & 5 \\
\hline \multirow{4}{*}{$\begin{array}{l}\text { Spring } \\
1996\end{array}$} & 1 & 14 & - & - & - & - & - & - & - \\
\hline & 2 & 9 & 1 & 11.1 & $/ 1$ & 1 & - & - & - \\
\hline & 3 & 1 & - & - & - & - & - & - & - \\
\hline & 4 & 15 & 5 & 33.3 & $5.0 / 1-13$ & 14 & 7 & 1 & 2 \\
\hline \multirow{4}{*}{$\begin{array}{l}\text { Summer } \\
1996-1997\end{array}$} & 1 & 31 & 3 & 9.7 & $2.0 / 1-4$ & 6 & - & - & - \\
\hline & 2 & 32 & 2 & 6.2 & $1.0 / 1-1$ & 1 & 1 & - & - \\
\hline & 3 & 31 & 8 & 25.8 & $1.4 / 1-4$ & 2 & 1 & 2 & 6 \\
\hline & 4 & 21 & 7 & 33.3 & $1.9 / 1-6$ & - & - & 3 & 8 \\
\hline \multirow{4}{*}{$\begin{array}{l}\text { Autumn } \\
1997\end{array}$} & 1 & 34 & 10 & 29.4 & $1.1 / 1-2$ & 2 & 4 & - & - \\
\hline & 2 & 46 & 14 & 30.4 & $2.0 / 1-6$ & 1 & 12 & - & 5 \\
\hline & 3 & 43 & 21 & 48.8 & $1.7 / 1-5$ & 3 & 17 & 2 & 7 \\
\hline & 4 & 55 & 18 & 32.7 & $1.7 / 1-6$ & 3 & 10 & 1 & 10 \\
\hline \multirow{4}{*}{\begin{tabular}{|l|} 
Summer \\
1997-1998
\end{tabular}} & 1 & 8 & - & - & - & - & - & - & - \\
\hline & 2 & 7 & - & - & - & - & - & - & - \\
\hline & 3 & 7 & - & - & - & - & - & - & - \\
\hline & 4 & 17 & 5 & 29.4 & 1.8/1-4 & - & 1 & 1 & 2 \\
\hline \multirow{4}{*}{$\begin{array}{l}\text { Autumn } \\
1998\end{array}$} & 1 & 21 & - & - & - & - & - & - & - \\
\hline & 2 & 23 & 1 & 4.3 & $/ 1$ & - & 1 & - & - \\
\hline & 3 & 17 & 3 & 17.6 & $1.3 / 1-2$ & 1 & 1 & - & 1 \\
\hline & 4 & 21 & 8 & 38.1 & $2.2 / 1-8$ & 1 & 4 & - & 13 \\
\hline \multirow{4}{*}{\begin{tabular}{|l|} 
Summer \\
$1998-1999$
\end{tabular}} & 1 & 21 & 4 & 19.0 & $1.5 / 1-2$ & 5 & 1 & - & - \\
\hline & 2 & 16 & 1 & 6.2 & 12 & - & 2 & - & - \\
\hline & 3 & 12 & 2 & 0.2 & 1/1-1 & - & 2 & - & - \\
\hline & 4 & 17 & 5 & 29.4 & $1.8 / 1-2$ & 4 & 1 & 1 & 3 \\
\hline \multirow[t]{4}{*}{ Autumn 1999} & 1 & 26 & 8 & 30.8 & $2.5 / 1-6$ & 7 & 7 & - & - \\
\hline & 2 & 21 & 14 & 66.7 & $1.8 / 1-4$ & 11 & 6 & 1 & 2 \\
\hline & 3 & 19 & 12 & 63.2 & $1.7 / 1-3$ & - & 7 & 4 & 5 \\
\hline & 4 & 17 & 12 & 70.6 & $1.7 / 1-6$ & 2 & 5 & 5 & 4 \\
\hline
\end{tabular}


TABLE 1

Continued..

\begin{tabular}{|c|c|c|c|c|c|c|c|c|c|}
\hline & \multirow{2}{*}{$\begin{array}{l}\text { Frog size } \\
\text { class }\end{array}$} & \multirow{2}{*}{\begin{tabular}{|c|}
$\#$ of frogs \\
analyzed
\end{tabular}} & \multirow{2}{*}{$\begin{array}{l}\text { \# of frogs } \\
\text { infected }\end{array}$} & \multirow{2}{*}{$\begin{array}{c}\text { Prevalence } \\
(\%)\end{array}$} & \multirow[t]{2}{*}{ Mean intensity/min.-max. } & \multicolumn{4}{|c|}{ \# of worms in stages } \\
\hline & & & & & & I & II & III & IV \\
\hline \multirow[t]{4}{*}{ Winter 1999} & 1 & 6 & 2 & 33.3 & $1.5 / 1-2$ & - & 1 & - & 2 \\
\hline & 2 & 16 & 11 & 68.7 & $1.4 / 1-3$ & - & 4 & 2 & 9 \\
\hline & 3 & 16 & 8 & 50.0 & $2.0 / 1-4$ & - & 5 & 1 & 7 \\
\hline & 4 & 15 & 10 & 66.7 & $2.1 / 1-4$ & - & 4 & 2 & 15 \\
\hline \multirow[t]{4}{*}{ Spring 1999} & 1 & 4 & 1 & 25.0 & $/ 1$ & 1 & - & - & - \\
\hline & 2 & 4 & 2 & 50.0 & $11.0 / 9-13$ & 16 & 6 & - & - \\
\hline & 3 & 14 & 6 & 42.9 & $1.8 / 1-4$ & 3 & - & - & 8 \\
\hline & 4 & 24 & 19 & 79.2 & $2.3 / 1-4$ & 1 & 6 & 4 & 29 \\
\hline \multirow{4}{*}{$\begin{array}{l}\text { Summer } \\
\text { 1999-2000 }\end{array}$} & 1 & 22 & 15 & 68.2 & $4.7 / 1-8$ & 27 & 13 & - & - \\
\hline & 2 & 8 & 4 & 50.0 & $5.0 / 3-9$ & 5 & 9 & - & 3 \\
\hline & 3 & 20 & 14 & 70.0 & $3.4 / 1-9$ & 4 & 17 & 8 & 3 \\
\hline & 4 & 15 & 12 & 80.0 & $4.2 / 1-15$ & - & 7 & 7 & 19 \\
\hline \multirow[t]{4}{*}{ Autumn 2000} & 1 & 19 & 6 & 31.6 & $1.3 / 1-2$ & 3 & 5 & - & - \\
\hline & 2 & 21 & 7 & 33.3 & $3.0 / 1-6$ & 11 & 8 & - & 1 \\
\hline & 3 & 44 & 28 & 63.6 & $1.9 / 1-4$ & 8 & 18 & 6 & 12 \\
\hline & 4 & 16 & 11 & 68.7 & $1.8 / 1-4$ & 5 & 10 & 2 & 2 \\
\hline \multirow[t]{4}{*}{ Winter 2000} & 1 & 1 & 1 & 50.0 & 13 & - & 3 & - & - \\
\hline & 2 & 12 & 9 & 75.0 & $1.8 / 1-3$ & - & 1 & 5 & 5 \\
\hline & 3 & 48 & 41 & 85.4 & $2.3 / 1-9$ & 3 & 13 & 5 & 25 \\
\hline & 4 & 15 & 13 & 86.7 & $2.1 / 1-6$ & - & 10 & 1 & 11 \\
\hline \multirow[t]{4}{*}{ Spring 2000} & 1 & 4 & 1 & 25.0 & 12 & - & 1 & - & 1 \\
\hline & 2 & 5 & 1 & 20.0 & 12 & - & 1 & 1 & - \\
\hline & 3 & 7 & 5 & 71.4 & $2.4 / 1-4$ & - & - & - & 10 \\
\hline & 4 & 40 & 30 & 75.0 & $2.0 / 1-4$ & - & 1 & 7 & 44 \\
\hline
\end{tabular}

et al., 2000). This parasite displayed a weak seasonal pattern of maturation, with the permanent presence of gravid worms with mature eggs. However, most of the mature parasite infrapopulations were present mainly during the coldest time of the year (Figs. 2 and 3a), as observed by Chubb (1979) in other species of trematodes in subtropical and tropical conditions. Most of the worms completed their egg production and were expelled from the host after hibernation, mainly during the warmest time of the year.

The recruitment periods of G. vitellinophilum were observed in summer, autumn and spring. This discontinuous new acquired infection (stage I) may be explained in more than one way: 1) the timing of cercariae release coincides with the appearance of a new L. limellus cohort in the pond (this was most noticeable during the warmest time of the year) (Fig. 3a); and 2) the annual rainfall changes presumably determine the population age structure of frogs (Kehr, pers. comm.). Worm recruitment declined in summer (Dec 1997 to Feb 1998) due to a dry period in the pond (Fig. 3b). Possibly, this differential seasonal recruitment production through the years results in a fortuitous adaptation that ensures the survival of the G. vitellinophilum population in the eventuality of an environmental catastrophe. Desiccation, a highly significant perturbation factor, plays a major role for these parasites and the age structure of the host infrapopulation (Kehr et al., 2000). 
The adult parasite (stage IV) showed several temporal variations between the fourth year (1999) and the preceding three years. Moreover, in the fourth year, the assembly of adult trematodes from winter to spring still appeared to be an overall response to high rainfall in the third year. However, in the following year (2000), the adult worm was present in each monthly sample as a densitydependent mechanism triggered to recover the initial infrapopulation level throughout the years.

In some host-parasite systems, the body size of the host is correlated with the body size of the parasite (Poulin, 1998). For instance, the relationship between parasite infection in the different developmental stages and the body length of the host suggests that the new generation of parasites infected small body sizes of L. limellus (classes 1 and 2). During this infection period, some frogs harbored a massive infection (maximum 15 in Jan 2000, see Table 1). Moreover, small parasites (stage 1) showed a positive and significant relationship between the host's body size and their own. This may have indicated an allometry of parasite recruitment with the host's body length. Thus, growth in this stage is clearly sizedependent, contributing to the parasite's long-term residence in the host and its future reproductive success. Juvenile and nongravid worms (stage II and III) showed a dependent relationship between the number of parasites and the frog's body length. Nevertheless, the parasite's body length in stage II revealed an independent relationship with the frog's body length. Lastly, the highest frequency of gravid worms (stage IV) was found in the frogs' adult body sizes (class 4 ) and displayed a positive relationship between the host's body length and its own. These findings suggest that the increase in G. vitellinophilum growth is dependent on the host's body size, which facilitates the evolution of G. vitellinophilum toward a larger body size and higher fecundity (trade-off).

In summary, the seasonal maturation of G. vitellinophilum in the host was probably dictated by environmental conditions, mainly dry and rainfall periods, since the temperature was not a limiting factor in determining seasonality on parasites in the Corrientes province. Moreover, the maturity of these parasites was associated with the spawning cycle of the host $L$. limellus, as a result of the correlation between the host's size structure and its endocrinal systems. Thus, the combination of these factors in addition to the abundance and availability of the intermediate host, including host nutrition and compatibility (e.g., immunology) of host and parasite (Esch \& Fernández, 1994), Fried \& Graczyk, 1997; Poulin, 1998), may have influenced the seasonal dynamics of parasite maturation in this aquatic ecosystem.

Acknowledgments - I would like to acknowledge the critical review and suggestions for the manuscript offered by Arturo I. Kehr.

\section{REFERENCES}

BUSH, A. K., LAFFERTY, D., LOTZ, J. M. \& SHOSTAK, A. W., 1997, Parasitology meets ecology on its own terms: Margolis et al. Revisited. J. Parasitol., 83: 575-583.

CHUBB, J. C., 1979, Seasonal occurrence of helminths in freshwater fishes. Part. II. Trematoda. Adv. Parasitol., 17: 141-313.

DUELlmAN, W. E. \& TRUEB, L., 1986, Biology of Amphibians. McGraw-Hill, New York. 670p.

ESCH, G. W. \& FERNANDEZ, J. C., 1994, Snail-trematode interactions and parasite community dynamics in aquatic systems: a review. Am. Midl. Nat., 131: 209-237.

FRIED, B. \& GRACZYK, T. K., 1997, Advances in Trematode Biology. CRC Press. Boca Raton, New York. 466p.

GRABDA-KAZUBSKA, B., 1976, Abbreviation of the life cycles of plagiorchid trematodes: general remarks. Acta Parasitol. Polonica, 24: 125-141.

HAMANN, M. I. \& KEHR, A. I., 1999, Populational dynamics and ecological relationships between Glypthelmins vitellinophilum Dobbin, 1958 (Trematoda, Macroderoididae) and the host Lysapsus limellus Cope, 1882 (Anura, Pseudidae) in a semipermanent pond of Argentina. Physis, 57: 17-24.

KEHR, A. I., MANLY, B. F. \& HAMANN, M. I., 2000, Coexistence of helminth species in Lysapsus limellus (Anura: Pseudidae) from an Argentinean subtropical area: influence of biotic and abiotic factors. Oecologia, 125: 549-558.

POULIN, R., 1998, Evolutionary Ecology of Parasites. From individuals to communities. Chapman \& Hall, London. 212p.

SMYTH, J. D. \& SMYTH, M. M., 1980, Frogs as Host-Parasite Systems I. An Introduction to Parasitology through the Parasites of Rana temporaria, R. esculenta and R. pipiens. The Macmillan Press Ltd. 112p.

YAMAGUTI, S., 1973, Synoptical Review of Life Histories of Digenetic Trematodes of Vertebrates. 590p. Japan, Kyoto.

ZAR, J. H., 1996, Biostatistical Analysis. Third Edition, prentice, Hall. 662p. 